\title{
PEDAGOGŲ KŪRYBIŠKUMĄ PROFESINĖJE VEIKLOJE LEMIANČIŲ VEIKSNIŲ ANALIZE்
}

\author{
Dalia Lapėniené $\dot{1}^{1}$ Skaistė Laskiené2 \\ Kauno Petro Vileišio vidurine mokykla ${ }^{1}$, Lietuvos kūno kultūros akademija ${ }^{2}$, Kaunas, Lietuva
}

Dalia Lapėnienė. Humanitarinių mokslų (anglų filologijos) magistrè. Vilniaus universiteto Kauno humanitarinio fakulteto doktorantė. Kauno Petro Vileišio vidurinės mokyklos direktorè. Mokslinių tyrimų kryptis — kūrybiškumo raiška profesinèje pedagogų veikloje.

\section{SANTRAUKA}

Pastaraisiais dešimtmečiais mokslininkai, analizuojantys organizaciju veikla, ypač susidomèjo socialiniu kūrybiškumu ir su juo susijusiais asmenybès faktoriais. Anot C. M. Ford ir D. A. Gioia (2000), kūrybiškumas turètu būti apibrèžiamas kaip subjektyvūs asmens veiklos rezultatai, nauji ir naudingi konkrečios veiklos sričiai. Kūrybiškumas analizuojamas kaip asmens kasdienio elgesio kūrybinio potencialo raiška (Nam Choi, 2004). Manoma, kad bütent kasdienis darbuotoju kūrybiškumas yra sèkmingos organizaciju veiklos garantas.

Mokymas yra specifinè profesinès veiklos sritis. Jai būdingas daugialypis socialinis kontekstas, kuris atveria galimybes asmens kūrybiškumo raiškai. Mokiniu kürybiškumo ugdymas Ł̇vardijamas kaip vienas svarbiausiu tikslu šiuolaikinio ugdymo procese (Welle-Strand, Tjeldvoll, 2003).

Šiuo požiūriu kūrybiškas mokymas ir mokytojo profesinis kūrybiškumas ypač svarbūs. Būtina ieškoti būdu, kaip ugdyti mokytoju kūrybiškuma profesineje veikloje, tačiau norédami tai daryti turime žinoti profesinès veiklos kūrybiškumo identifikavimo büdus.

Tyrimo tikslas — ¿vertinti darbo motyvacijos ir darbe išgyvenamu nuotaiku poveiki pedagogu kūrybiškumui profesinejje veikloje. Tyrimo klausimyno metodologini pagrindq sudaro S. Farmer, P. Tierney, K. Kung-McIntyre (2003), P. Tierney ir S. Farmer (2002), S. A. Kornacki ir D. R. Caruso (2007), N. H. Leonard, L. L. Beauvais ir R. W. Scholl (1999) darbai. Tyrimo metu apklausta 190 mokytoju. Duomenu analize atlikta naudojant SPSS 16.0 for Windows programa.

Gautas atitikmuo tarp teoriškai apibrëžtu kūrybiškuma profesinėje veikloje lemiančiu veiksniu ir empirinio tyrimo rezultatu. Išskirtas suvokiamo kūrybiškumo profesineje veikloje ir šeši individo lygmens faktoriai, apibūdinantys kūrybinį saviveiksminguma, darbe patiriamas emocijas ir darbo motyvacijos šaltinius. Penki iš ju statistiškai reikšmingai susiję su subjektyviu mokytoju kūrybiškumu profesineje veikloje: kūrybinis saviveiksmingumas, pozityvios emocijos, vidinio tikslo motyvacija, vidine proceso ir išoriné savivaizdžio motyvacija.

Raktažodžiai: kūrybiškumas, profesinè veikla, kūrybinis saviveiksmingumas.

\section{IVADAS}

K ūrybiškumo svarba šiandieninèje visuomeneje neabejotina. Kūrybiškumas jau seniai peržengè tiek psichologijos, tiek bet kurios kitos disciplinos ribas. R. S. Albert ir M. A. Runco (1999) nurodo, kad vienoks ar kitoks požiūris ị kūrybiškumą egzistavo nuo pat Vakarų civilizacijos pradžios. Tačiau tik XX amžiaus pradžioje kūrybiškumas imtas tyrinèti naudojant mokslinius metodus. Pirmieji kūrybiškumo tyrimai atlikti naudojant atvejo analizès metodą psichodinaminès teorijos pagrindu. Vèlesnių tyrimų metu pritaikytas psichometrinis požiūris kūrybiškumas vertintas naudojant psichologinius, panašius į inteligentiškumo, testus (Sternberg, Lubart, 1999). Kūrybiškumo tyrimai lèmė šio fenomeno demistifikavimą - jei pirmų tyrimu metu kūrybiškais laikyti išskirtiniu gebejimų asmenys, tai šiuolaikiniai tyrimai kūrybiškumą trak- 
tuoja kaip tam tikru lygiu pasireiškiantị gebejjimą kiekvieno asmens kasdienèje veikloje. Kasdienis kūrybiškumas čia suprantamas kaip polinkis ieškoti ir taikyti originalias idejas, sprendimus ar veiklos būdus. Šiuo požiūriu mokytojo kasdienis kūrybiškumas reiškiasi polinkiu išmėginti naujus darbo metodus, taikyti naujas kompetencijų ugdymo, mokinių motyvavimo, pasiekimų vertinimo ir kitas priemones. Kasdienis kūrybiškumas lemia kūrybinių gebejjimų lavinimą, o lavinami kūrybiniai gebejjimai veda prie didžiujų, išskirtiniu kūrybinių laiméjimų. Atsižvelgiant i kasdienio kūrybiškumo svarbą, šiuolaikiniai organizaciju tyrinètojai kuria ir tobulina priemones, kurios leidžia ìvertinti darbuotoju kasdieni kūrybiškumą. Kūrybiškumas organizaciju aplinkoje yra apibrèžiamas kaip kūrybinė veikla, lemianti kūrybiškus rezultatus, o vertinamas kaip nuostatos savo gebèjimu atžvilgiu, pasiektų rezultatu isivertinimas ar kolegų vertinimas. Šiuolaikinių tyrimų metu kūrybiškumas profesineje veikloje vertinamas pasitelkus klausimynus, taip pabrèžiant subjektyvią kūrybiškumo prigimtị. Straipsnyje vadovaujamasi C. M. Ford ir D. A. Gioia (2000) apibrèžimu, kad kūrybiškumas, kylantis iš individo subjektyvios patirties ir supratimo, yra naujų ir naudingų rezultatu gavimas tam tikroje srityje.

Problemos aktualumas. Kūno kultūros mokytojai yra specifinè profesinè bendruomenè. Ju veikla sudaro galimybę reikštis kasdieniam kūrybiškumui profesinejje veikloje. Nepaisant to, tiek kūno kultūros, tiek kitų specialybių mokytojų kasdienis kūrybiškumas yra mažai tyrinètas. Ši problema ypač aktuali Lietuvoje. Analizuojant kūrybiškumo sąvokos prasmes išryškejja akivaizdi disciplinų izoliacija ir teoriškai ribotas kūrybiškumo supratimas. Kūrybiškumas analizuojamas psichologijos pagrindu. Čia svarus J. Almonaitienès (2000), D. Karkockienès ir G. Butkienès (2005), D. Grakauskaitės-Karkockienès $(2002,2006)$ indèlis. Savitą potekstę kūrybiškumo problema igauna filosofiniu požiūriu - T. Kačerauskas (2005, 2007), V. Pruskus (2005) savo tyrimais plètoja A. Maceinos (1991) filosofinę mintị. Kūrybiškumo ugdymas sulaukia vis daugiau mokslininku dèmesio (pvz., Ponelienès, Gumliauskienès, 2008; Domeikienès, 2005; Petrulytès, 2008). Didžioji dalis Lietuvos mokslininkų kūrybiškumą ugdymo srityje, mokinių kūrybiškumą, jo raišką, ugdymo galimybes analizuoja iš ịvairiu perspektyvų. Pedagogų kūrybiškumas sukuria mokinių kūrybiškumą lavinančią aplinką, t. y. tik kūrybiškai dirbantys mokytojai išugdo kūrybiškus mokinius.
Straipsnyje ginama idèja, kad mokytojai yra kūrybiški, tačiau jų kūrybiškumą lemia požiūris i savo gebejjimus, motyvacija ir nuotaika užsiimant profesine veikla.

Tyrimo tikslas — ivertinti darbo motyvacijos ir darbe išgyvenamų nuotaikų poveiki pedagogu kūrybiškumui profesinèje veikloje.

Uždaviniai - išskirti ir apibūdinti:

- Pedagogų kūrybiškumo raišką profesinèje veikloje.

- Pedagogu profesinés veiklos motyvacijos šaltinius.

- Pedagogų nuotaikų, patiriamų užsiimant profesine veikla, ypatumus.

\section{TYRIMO METODAI}

Tyrimo metodas: anketinè apklausa raštu. Tiriamiesiems pateiktas klausimynas, sudarytas atsižvelgiant ị tyrimo tikslą ir uždavinius. Pirmą klausimyno dalị sudaro 19 teiginių, susijusių su kūrybinio saviveiksmingumo ir suvokiamo kūrybiškumo raiška. Tiriamujų prašoma ìvertinti kiekvieną teigini R. Lickert (1932) skalès principu pasirenkant reikšmę nuo „visiškai nesutinku“ (atitinka 1 reikšmę) iki „visiškai sutinku (atitinka 5 reikšmę). Antros klausimyno dalies tikslas ivvertinti, kaip dažnai tiriamieji išgyvena įvairias nuotaikas darbe. Šią dali sudaro devyni emociju pavadinimai, kuriuos prašoma įvertinti skalèje nuo „beveik niekuomet“ (atitinka 1 reikšmę) iki „labai dažnai“ (atitinka 5 reikšmę). Trečioje dalyje pateikta 19 teiginių tiriamuju darbo motyvacijos šaltiniui ivvertinti. Teiginiams vertinti naudota skalè nuo „visiškai nesutinku“ (atitinka 1 reikšmę) iki „visiškai sutinku (atitinka 5 reikšmę).

Tiriamųjų kontingentas: 2008 metais Lietuvoje atliktas pedagogų, dirbančių Kauno mieste, tyrimas. Tiriamujų atranka vykdyta dviem etapais. Per pirmą etapą buvo naudojamas klasterinis atrankos sudarymo metodas - pasirinktos keturios mokyklos, per antrą — pedagogai atsitiktinai pasirinkti iš mokyklų darbuotojų sąrašų. Tiriamuju skaičių lèmé bendras kiekvienos ir tirtų mokyklų pedagogu skaičius. Kiekvienoje iš tirtu mokyklu apklausta ne mažiau kaip $70 \%$ pedagogų. Iš viso apklausta 190 tiriamujų: A mokykloje $-29 \%$, $\mathrm{B}-27 \%, \mathrm{C}-16 \%$, D - 28\%. Atsako dažnis - $95 \%$. Garantavus rezultatų konfidencialumą, tiriamieji sutiko dalyvauti tyrime.

Tyrimo duomenų analizė atlikta naudojant SPSS 16.0 for Windows programą, faktorinè klausimyno analizè - esminiu komponenčiu metoda 
ir Varimax rotacijos principą. I faktorinę analize itraukti tik normaliojo skirstinio dessningumus atitinkantys teiginiai. Teiginiai, kurių koreliacija su faktoriumi mažesnè nei 0,2 , i skalių sudarymą neitraukti. Koreliacijai tarp skalių nustatyti naudotas Pirsono $r$ koreliacijos koeficientas, ivertinant tai, kad skalių duomenų išsibarstymas atitinka normaliojo skirstinio principus.

Tyrimo metodologijos pagrindimas. Metodologini tyrimo pagrinda sudaro: S. Farmer, P. Tierney ir K. Kung-McIntyre (2003) suvokiamo kūrybiškumo, vertinant elgesi praeityje, faktorius; P. Tierney ir S. Farmer (2002) kūrybinio saviveiksmingumo faktorius; S. A. Kornacki ir D. R. Caruso (2007) pagrindinių emocijų klasifikacija; N. H. Leonard, L. L. Beauvais ir R. W. Scholl (1999) motyvacijos šaltinių klasifikacija.

P. Tierney ir S. Farmer (2002), S. Farmer, P. Tierney ir K. Kung-McIntyre (2003) apibrèžia ryšius tarp asmens savivaizdžio ir jo kūrybiškumo. Jie pirmieji pritaikè klasikinę A. Bandura saviveiksmingumo savoką kūrybinei veiklai aiškinti. Šie autoriai teigia, kad kūrybinis saviveiksmingumas - tai „tikèjimas savo gebėjimu sukurti kūrybišką produktą“ (Tierney, Farmer, 2002). Jų teigimu, kūrybinis saviveiksmingumas, kurio patikimumas irodytas empiriniais tyrimais, yra unikali visų kūrybiškų žmonių savivaizdžio dalis. Savo idejas apie kūrybiškumo ir savivaizdžio ryšius autoriai plètoja pateikdami subjektyvaus kūrybiškumo, ir kūrybinio vaidmens tapatumo sąvokas (Farmer et al., 2003). Anot jų, savęs laikymas kūrybišku žmogumi yra galinga darbuotoju kūrybiškumo prielaida. Taikant šias sąvokas ir analizuojant mokytojo kūrybiškumą keliama ideja, kad profesinis mokytojų kūrybiškumas kyla iš kūrybinès veiklos ísivertinimo, pasitikejjimo turimais kūrybiniais gebejjimais.

S. A. Kornacki ir D. R. Caruso (2007) suklasifikavo pagrindines emocijas, išvardydami jausmų spektrą nuo stiprių teigiamų iki stiprių neigiamų. Būtent ši klasifikacija sudaro nuotaikos darbe tyrimo metodologini pagrindą. Apibrèžiant nuotaikos terminą buvo remtasi K. James ir kt. (2004) siūlymu emocijomis laikyti trumpalaikes jausmines reakcijas, o ilgalaikius ir intensyvius jausmus vadinti nuotaikomis. Kadangi tiriamuju buvo prašoma nurodyti, ar klausimyne išvardytus jausmus jie išgyvena labai dažnai, gautieji duomenys leidžia daryti išvadas apie mokytojams būdingas nuotaikas.

N. H. Leonard, L. L. Beauvais ir R. W. Scholl (1999) apibendrino ivvairių autorių pateiktas moty- vacijos koncepcijas ir atlikę metaanalizę pateike motyvacijos šaltinių klasifikaciją. Šioje taksonomijoje vartojama motyvacijos šaltinio sąvoka apibūdina motyvų kilmę. Išskiriami penki motyvacijos šaltiniai:

- Vidine proceso motyvacija. Ją lemia mègavimasis užduotimi, kuri individui svarbesnè nei atlygis už darbą. Darbas atitinka individo poreikius ir interesus, todèl jaučiama motyvacija pačiam veiklos procesui, o individas džiaugiasi galimybe dirbti.

- Instrumentine motyvacija - apčiuopiami naudos lūkesčiai. Instrumentinè motyvacija — tai paskata turèti pinigu, privilegijų ir kitų apčiuopiamų atlygio formų.

- Išorine savivaizdžio motyvacija. Ją lemia poreikis išlaikyti reputacija. Svarbi žmonems, kurie siekia pateisinti aplinkinių lūkesčius. Aplinkinius tenkinantis elgesys leidžia jaustis pastebetam, priimtam.

- Vidiné savivaizdžio motyvacija - poreikis pateisinti sau keliamus reikalavimus. Tai pasiekimų, savireguliacijos, nuolatinio tobulèjimo motyvacija.

- Vidinio tikslo motyvacija svarbi asmenims, kurių nuostatas ir elgesi lemia vertybių sistema. Žmogus tvirtai tiki siekiamų tikslų svarba ir verte. Idealai, issitikinimai ir jaučiama pareiga yra svarbiausi motyvai.

\section{REZULTATAI}

Tyrimo duomenys apdoroti trim etapais. Per pirmą etapą atlikta faktorinè duomenų analizè, per antra - ivertintas kiekvienam faktoriui priskirto teiginio turinys, per trečią - nustatyti koreliaciniai ryšiai tarp faktorių.

Literatūroje kūrybiškumas nagrinèjamas remiantis asmens suvokimu apie savo gebėjimus kurti. Būtent šis suvokimas lemia, ar individas yra linkęs plètoti savo kūrybines galias, imtis kūrybinès veiklos profesinejje veikloje. Remiantis teoriniais kūrybinio saviveiksmingumo ir suvokiamo kūrybiškumo aprašymais buvo sukurtos dvi skalès, kuriu pagristumui patvirtinti naudota faktorinès analizès procedūra. Esant teorinių konstruktų ir empirinių duomenų atitikimui buvo laukiama, kad kūrybinis saviveiksmingumas ir suvokiamas kūrybiškumas sudarys du atskirus faktorius. Faktorinès analizès rezultatai pateikiami 1 lentelejje.

Faktorinès analizès rezultatai liudija esant du nepriklausomus faktorius, kurių kiekvienas parodo svarbų, su kūrybinių gebèjimų i̊sivertinimu susi- 
1 lentelè. Kūrybiškumą profesinèje veikloje parodančių teiginių faktorinès analizès rezultatai

\begin{tabular}{|c|c|c|c|}
\hline Faktorius & Faktoriui priskirti teiginiai & $\begin{array}{l}\text { Teiginių ryšio su } \\
\text { faktoriumi stiprumas }\end{array}$ & $\begin{array}{l}\text { Dispersijos dalis, kurią } \\
\text { paaiškina faktorius, \% }\end{array}$ \\
\hline \multirow{10}{*}{$\begin{array}{l}\text { 1. Kūrybinis saviveiks- } \\
\text { mingumas }\end{array}$} & Man svarbu ugdyti mokinių kūrybiškumą & 0,805 & \multirow[t]{10}{*}{28,75} \\
\hline & Manau, mokytojo darbas ịpareigoja būti kūrybišku & 0,768 & \\
\hline & Dirbti kūrybiškai skatina siekis tobulèti & 0,739 & \\
\hline & Gebu pateikti idejų, kai to reikia & 0,636 & \\
\hline & Stengiuosi nuolat kažką daryti vis kitaip & 0,630 & \\
\hline & $\begin{array}{l}\text { Spręsdama(-s) problemas stengiuosi įžvelgti } \\
\text { originalius sprendimo būdus }\end{array}$ & 0,620 & \\
\hline & $\begin{array}{l}\text { Dirbdama(-s) kūrybiškai jaučiu, kad tai, ką darau, } \\
\text { yra prasminga }\end{array}$ & 0,620 & \\
\hline & $\begin{array}{l}\text { Pasitikiu savo gebejjimais kūrybiškai spręsti } \\
\text { problemas }\end{array}$ & 0,619 & \\
\hline & Pateikiu naują požiūrị i senas problemas & 0,584 & \\
\hline & $\begin{array}{l}\text { Suvokdama(-s) problemą visuomet apgalvoju kuo } \\
\text { daugiau būdų, kaip būtų galima ją spręsti }\end{array}$ & 0,459 & \\
\hline \multirow[t]{7}{*}{ 2. Suvoktas kūrybiškumas } & Esu lakios vaizduotès & 0,731 & \multirow[t]{7}{*}{21,12} \\
\hline & Mokau kolegas dirbti kūrybiškai & 0,688 & \\
\hline & $\begin{array}{l}\text { Man pasiseka atlikti kūrybiškumo reikalaujančią } \\
\text { veiklą geriau nei daugumai kolegų }\end{array}$ & 0,674 & \\
\hline & Visuomet turiu idejjų, ką dar galèčiau padaryti & 0,670 & \\
\hline & Nebijau pasirodyti kvailesnè(-is) & 0,580 & \\
\hline & Save laikau kūrybišku mokytoju & 0,544 & \\
\hline & Gebu susidoroti su keletu problemų tuo pačiu metu & 0,525 & \\
\hline \multicolumn{4}{|c|}{ Iš viso pasirinktas modelis paaiškina 49,88 gautos informacijos } \\
\hline $\begin{array}{l}\text { Faktorinès analizės reikšm } \\
\text { - KMO kriterijus = } 0,878 \text {; } \\
\text { - } \text { Bartlett testas apytikslis }\end{array}$ & dratas $=4037202$ su 171 laisvés lainsniu kai & 001. & \\
\hline
\end{tabular}

2 lentelè. Nuotaikas individo profesinėje veikloje parodančių emocijų faktorinès analizės rezultatai

\begin{tabular}{|c|c|c|c|}
\hline Faktorius & Faktoriui priskirti teiginiai & $\begin{array}{c}\text { Teiginių ryšio su } \\
\text { faktoriumi stiprumas }\end{array}$ & $\begin{array}{l}\text { Dispersijos dalis, kurią } \\
\text { paaiškina faktorius, \% }\end{array}$ \\
\hline \multirow[t]{4}{*}{ Negatyvios emocijos } & Nusivylimas & 0,836 & \multirow[t]{4}{*}{25,80} \\
\hline & Liūdesys & 0,773 & \\
\hline & Pyktis & 0,755 & \\
\hline & Pasitenkinimas atliktu darbu & $-0,228$ & \\
\hline \multirow[t]{3}{*}{ Pozityvios emocijos } & Susidomèjimas & 0,847 & \multirow[t]{3}{*}{19,40} \\
\hline & Džiaugsmas & 0,757 & \\
\hline & Abejingumas & $-0,559$ & \\
\hline \multirow[t]{2}{*}{ Neutralios emocijos } & Atsipalaidavimas & 0,836 & \multirow[t]{2}{*}{14,26} \\
\hline & Pasimetimas & 0,459 & \\
\hline \multicolumn{4}{|c|}{ Iš viso pasirinktas modelis paaiškina $59,47 \%$ gautos informacijos } \\
\hline $\begin{array}{l}\text { Faktorinės analizės rei } \\
\text { - } \text { KMO kriterijus = } \\
\text { - } \text { Bartlett testas apytik }\end{array}$ & auratas - $1409,4 / 0$ su 50 lalsves lal & 0,001 . & \\
\hline
\end{tabular}

jusi fenomeną. Kūrybinio saviveiksmingumo faktorius sutampa su P. Tierney ir S. Farmer (2002) kūrybinio saviveiksmingumo fenomenu, rodančiu pasitikèjimą savo gebejjimais kūrybiškai dirbti ir apima būtent tuos teiginius, kurie susiję su savęs isivertinimu kūrybinès veiklos, metodų požiūriu. Subjektyvaus kūrybiškumo faktorius sutampa su S. Farmer, P. Tierney ir K. Kung-McIntyre (2003) požiūrio i̇ savo kūrybišką elgesị koncepcija, pabrěžiančia, kad kūrybiškumą profesinèje veikloje daugiausia lemia darbuotojo vaidmens tapatumas. Kūrybiškas vaidmens tapatumas S. Farmer, P. Tierney ir K. Kung-McIntyre (2003) pateiktame modelyje laikomas būtina sąlyga kūrybiškumui ir apima du aspektus: savo elgesio isivertinimą kaip kūrybiško ir suvokiamus bendradarbiu kūrybiškumo lūkesčius, kad kolega dirbs kūrybiškai. Pirmas aspektas šio tyrimo metu laikomas kūrybiškumo prielaida, lemiančia mokytoju profesini kūrybiškumą. Suvokiamo kūrybiškumo faktorius 
3 lentelè. Darbo motyvaciją apibūdinančių teiginių faktorinès analizès rezultatai

\begin{tabular}{|c|c|c|c|}
\hline $\begin{array}{c}\text { Faktorius } \\
\text { (motyvacija) }\end{array}$ & Faktoriui priskirti teiginiai & $\begin{array}{c}\text { Teiginių ryšio su fak- } \\
\text { toriumi stiprumas }\end{array}$ & $\begin{array}{l}\text { Dispersijos dalis, kurią } \\
\text { paaiškina faktorius, \% }\end{array}$ \\
\hline \multirow[t]{8}{*}{ Vidinio tikslo } & Jaučiu pareigą kokybiškai dirbti & 0,847 & \multirow[t]{8}{*}{26,74} \\
\hline & Noriu duoti mokiniams geriausia, ką gebu & 0,826 & \\
\hline & Man svarbu nuolat tobulinti savo darbą & 0,783 & \\
\hline & $\begin{array}{l}\text { Dirbu taip, kad jausčiausi patenkinta(-s) savo darbo } \\
\text { rezultatais }\end{array}$ & 0,744 & \\
\hline & Dirbdama(-s) siekiu užsibrèžtų tikslų & 0,743 & \\
\hline & $\begin{array}{l}\text { Dirbu taip, kaip man diktuoja turimi moraliniai } \\
\text { isitikinimai }\end{array}$ & 0,680 & \\
\hline & Profesinė kvalifikacija man yra vertybė & 0,642 & \\
\hline & Man patinka dirbti su mokiniais & 0,576 & \\
\hline \multirow[t]{7}{*}{ Išorinè savivaizdžio } & Noriu būti pavyzdžiu savo kolegoms & 0,818 & \multirow[t]{7}{*}{22,09} \\
\hline & Noriu būti viena(-s) geriausiu mokytojų mokykloje & 0,751 & \\
\hline & Tinkamai dirbdama(-s) noriu būti paaukštintas & 0,748 & \\
\hline & Nenoriu atsilikti nuo gerai dirbančių kolegu & 0,680 & \\
\hline & $\begin{array}{l}\text { Man svarbu žinoti, kad kolegos laiko mane kompe- } \\
\text { tentingu }\end{array}$ & 0,641 & \\
\hline & $\begin{array}{l}\text { Man svarbi mokyklos vadovų nuomonè apie mano } \\
\text { darbą }\end{array}$ & 0,637 & \\
\hline & $\begin{array}{l}\text { Tobulinti darbą mane motyvuoja noras kelti kvalifi- } \\
\text { kacinę kategoriją }\end{array}$ & 0,600 & \\
\hline \multirow[t]{4}{*}{ Vidinè proceso } & Darbo procesas man svarbesnis nei atlyginimas už ji & 0,748 & \multirow[t]{4}{*}{9,77} \\
\hline & Mokytojo darbas man įdomus & 0,582 & \\
\hline & Dirbti mane skatina noras gauti didesni atlyginimą & $-0,577$ & \\
\hline & Esu patenkinta(-s) savo darbu & 0,380 & \\
\hline \multicolumn{4}{|c|}{ Iš viso pasirinktas modelis paaiškina $58,60 \%$ gautos informacijos } \\
\hline \multicolumn{4}{|c|}{$\begin{array}{l}\text { Faktorinės analizès reikšmin } \\
\text { - } \mathrm{KMO} \text { kriterijus }=0,880 \text {; }\end{array}$} \\
\hline
\end{tabular}

rodo individo nuomonę apie save, kūrybos galios turejjimą. Teiginių formuluotès orientuotos i pagrindinių kūrybiškumo gebejjimų issivertinimą. Faktorinès analizès rezultatai leidžia teigti, kad teoriškai numatyta klausimyno struktūra patvirtinta empiriniais duomenimis.

Emocijų ir kūrybiškumo sąsajos analizuojamos T. M. Amabile ir kt. (2005) pateiktame modelyje, kur emocijos yra ne tik kūrybiškumo priežastis, bet ir pasekmè. Viena vertus, teigiamos emocijos stimuliuoja mąstymo procesus, aktyvindamos divergentinị mąstymą. Kita vertus, kūrybiški rezultatai ir jų socialinis vertinimas provokuoja teigiamas emocijas. Minètų autorių kūrybiškumo organizacijose modelyje emocijos pateikiamos apibendrinta samprata, todèl sudarant skalę remtasi S. A. Kornacki ir D. R. Caruso (2007) pagrindinių emocijų klasifikacija. Faktorinès analizès rezultatai pateikiami 2 lenteleje.

Faktorinès analizès metu buvo išskirti trys veiksniai, parodantys teigiamas, neigiamas ir neutralias emocijas. Negatyvių emocijų faktorius rodo nepasitenkinimą atliekamu darbu ir pasiektu rezul- tatu. I ji jeina nusivylimo, liūdesio, pykčio jausmai. Atsakymų dèsningumai atskleide, kad tikètina šių jausmu priežastis - nepasitenkinimas darbu ir jo rezultatu. Pozityvių emocijų faktorius apima susidomejjimo ir džiaugsmo emocijas, kurios susijusios su kūrybiškumui svarbiu neabejingumo pojūčiu, noru įsitraukti i profesinę veiklą. Neutralios emocijos apima atsipalaidavimą ir pasimetimą, būdingą asmenims, nelinkusiems ịsitraukti ir aktyviai dalyvauti socialiniame gyvenime. Šis neutralumas neturètų pozityviai veikti profesinio kūrybiškumo. Apibendrinant gautus duomenis galima konstatuoti, kad pasitvirtino teoriškai numatytų teigiamų ir neigiamu emocijų faktorių egzistavimas. Neutralios emocijos sudaro atskirą faktorių.

Išanalizavus mokslinę literatūrą, nagrinèjančią kūrybiškumą profesinèje veikloje lemiančius veiksnius, galima teigti: darbo motyvacija yra viena esminių kūrybiškumo profesinejje veikloje prielaidų. Kaip jau minejome anksčiau, motyvacijos svarba akcentuojama T. M. Amabile (1996), B. A. Hennessey (2003), A. Cropley (2006) ir kitu autorių, plètojančių socialini požiūrị i kūrybišku- 


\begin{tabular}{|l|l|c|}
\hline Eil. Nr. & \multicolumn{1}{|c|}{ Skalëje analizuojamas fenomenas } & Kronbacho $\boldsymbol{\alpha}$ koeficientas \\
\hline 1. & Kūrybinis saviveiksmingumas & 0,884 \\
\hline 2. & Suvokiamas kūrybiškumas & 0,805 \\
\hline 3. & Negatyvios emocijos & 0,741 \\
\hline 4. & Pozityvios emocijos & 0,613 \\
\hline 5 & Vidinio tikslo motyvacija & 0,904 \\
\hline 6. & Išorinė savivaizdžio motyvacija & 0,859 \\
\hline 7. & Vidinė proceso motyvacija & 0,650 \\
\hline
\end{tabular}

4 lentelè. Faktorinės analizės metu išgrynintų skalių vidinio suderinamumo koeficientai

mą, darbuose. Isitraukimo ị veiklą priežastis paaiškina N. H. Leonard, L. L. Beauvais ir R. W. Scholl (1999) pateikta motyvacijos šaltinių klasifikacija. Šių teorinių konstruktų empirinis verifikavimas buvo atliktas naudojant faktorinès analizès procedūrą. Faktorinès analizès rezultatai pateikiami 3 lentelèje.

Klausimyno teiginių pagrindu tapo N. H. Leonard, L. L. Beauvais ir R. W. Scholl (1999), Barbuto Jr. (2005) teoriniai fenomenu aprašymai. Faktorinès analizès metu vietoje lauktu penkiu išskirti trys faktoriai. Pirmas faktorius apima vidinio tikslo motyvacijos ir vidinès savivaizdžio motyvacijos šaltinius. Vidinio tikslo motyvacijos samprata artima savirealizacijos sąvokai ir apibūdinama asmens noru dirbti vardan idejų, vertybiu ar jaučiamos pareigos, pašaukimo. Vidinè savivaizdžio motyvacija apibūdinama kaip ,aš“ idealo siekimas, sau keliamų reikalavimu igyvendinimas. Atsižvelgiant ị tai, kad vidinio tikslo motyvacija apibūdinantys teiginiai rodo stipriausią koreliaciją su faktoriumi, pirmasis ivvardijamas kaip vidinio tikslo motyvacijos faktorius.

Antras faktorius apima instrumentinès motyvacijos ir išorinès savivaizdžio motyvacijos šaltinius. Instrumentinè motyvacija apibūdinama kaip konkretaus atlygio motyvacija, besiremianti supratimu, kad kiekvienas darbas turi savo kaina. Išorinè savivaizdžio motyvacija sietina su socialiniu atlygiu, kuomet individui svarbu priemimas ir statusas grupejje. Analizuojant teiginių ryšio su faktoriumi stiprumą pastebėtini išorinès savivaizdžio motyvacijos teiginiai, labiausiai susije su faktoriumi, taigi jis įvardijamas kaip išorinès savivaizdžio motyvacijos faktorius.

Trečias faktorius parodo vidinès proceso motyvacijos šaltini, kuris apibūdinamas kaip kylantis iš paties veiksmo, o ne laukiant rezultato. Kūrybiškumo svarba motyvacinès veiklos procese pabrěžiama B. A. Hennessey (2003) tyrimais. Vidinè proceso motyvacija lemia tiek bendrają profesinès veiklos kokybę, tiek kūrybiškumą profesinejje veikloje.

Apibendrinant faktorinès analizès rezultatus galima teigti, kad nepavyko patvirtinti teoriškai numatytos motyvacijos šaltinių struktūros. Tai galëjo lemti pedagoginès veiklos specifika, kuomet išorinès savivaizdžio motyvacijos šaltinis kur kas dažniau stimuliuojamas nei vidinès, o materialaus skatinimo už profesinès veiklos rezultatus galimybès yra minimalios, pasiekiamos tik daliai mokytojų, atsižvelgiant i mokyklos galimybes.

Kūrybiškumą profesinejje veikloje lemia daug ivvairaus pobūdžio individo lygmens faktorių. Remiantis teorine problemos analize, išskirti kaip ypač svarbūs ir ištirti trys faktoriai: savo kūrybinio potencialo isivertinimas, emocijos, patiriamos darbe, ir profesines veiklos motyvacija. Nè vienas iš šių fenomenų nėra vienalytis, o faktorinès analizès duomenys atskleidžia, kad ištirta tik pusè minètu fenomenų raiškos atspalvių. Nepaisant šio trūkumo, gautieji faktoriai sumuojami į atitinkamas matavimo skales, kuriomis remiasi tolesnè fenomenu svarbos analizè.

Individo profesinio kūrybiškumo veiksnius parodančių skalių vidinis suderinamumas. Kalbant apie kūrybiškumą lemiančius veiksnius, būtina nustatyti vidini anksčiau minètų skalių suderinamumą. Kūrybiškumą lemiančiais veiksniais laikomi visi faktorinès analizès metu nagrinètieji.

Skaičiuojant vidinio suderinamumo koeficientus, kiekvienai iš skaliu buvo naudojamas Kronbacho $\alpha$ koeficientas. Šis vidinio suderinamumo rodiklis pasirinktas pagal duomenų pobūdį. Atsižvelgiant i M. Forshaw (2007) rekomendacijas laikyta, kad skalè atitinka statistinio patikimumo reikalavimus, jei Kronbacho $\alpha$ koeficientas didesnis nei 0,65 . Duomenys pateikiami 4 lenteleje.

Neutraliu emocijų skale pašalinta iš tolimesnès statistinès analizès, nes šios skalès Kronbacho $\alpha$ koeficientas lygus 0,149. Pozityvių emociju skalès Kronbacho $\alpha$ koeficientas lygus 0,613 , tačiau ši skalè i tolesnę duomenu analizę itraukta dèl matuojamos sąvokos svarbos profesinio kūrybiškumo prielaidų analizei. Didžiausias vidinio suderinamumo koeficientas nustatytas vidinio tikslo motyvacijos, kūrybinio savaveiksmingumo ir individualios paramos darbuotojui skalèmis. Vidinio suderinamumo kriterijus, taikomus grupiniu tyrimu metu, tenkina visos likusios skalès. Re- 
5 lentelè. Suvokiamo kūrybiškumo profesinẻje veikloje ir individo lygmens faktorių koreliaciniai ryšiai

Pastaba. $* *-\mathrm{p}<0,01$

\begin{tabular}{|l|c|}
\hline \multicolumn{1}{|c|}{ Individo lygmens faktoriai } & Suvokiamas kūrybiškumas \\
\hline Kūrybinis saviveiksmingumas & $0,610^{* *}$ \\
\hline Negatyvios emocijos & $-0,086$ \\
\hline Pozityvios emocijos & $0,369^{* *}$ \\
\hline Vidinio tikslo motyvacija & $0,413^{* *}$ \\
\hline Išorinė savivaizdžio motyvacija & $0,506^{* *}$ \\
\hline Vidiné proceso motyvacija & $0,384^{* *}$ \\
\hline
\end{tabular}

miantis statistinio patikimumo analizès rezultatais sudarytos septynios skalès, matuojančios individo lygmens fenomenus.

Kūrybiškumo profesinèje veikloje sąsajos su kūrybiniu saviveiksmingumu, emocijomis ir darbo motyvacija. Faktorinè analizè leido išskirti individo lygio veiksnius, teoriškai lemiančius kūrybiškumą profesinejje veikloje. Koreliacinè analizè leido îvertinti, ar analizuoti individo lygmens veiksniai (kūrybinis saviveiksmingumas, emocijos ir motyvacijos šaltiniai) yra susiję su suvokiamu kūrybiškumu profesinejje veikloje. Rezultatai pateikiami 5 lenteleje.

Gauti duomenys pagrindžia, kad kūrybinis saviveiksmingumas stipriai ir statistiškai reikšmingai koreliuoja su suvokiamu kūrybiškumu profesineje veikloje. Neigiamos emocijos neveikia mokytojų kūrybiškumo: nustatytas labai silpnas ir statistinio reikšmingumo neturintis ryšys. Savo ruožtu pozityvios emocijos ir kūrybiškumas susiję vidutiniškai, tačiau statistiškai reikšmingai. Visi trys darbo motyvacijos šaltiniai statistiškai reikšmingai lemia suvokiamą kūrybiškumą profesinejje veikloje, tačiau labiausiai veikia išorinè savivaizdžio motyvacija.

Apibendrinant koreliacinès analizès metu gautus duomenis galima konstatuoti, kad sudarytasis teorinis modelis pasitvirtino. Suvokiamas kūrybiškumas, kylantis iš kūrybinès veiklos praeityje, glaudžiai susijęs su kūrybiniu saviveiksmingumu, darbe išgyvenamomis pozityviomis emocijomis ir darbo motyvacijos šaltiniais.

\section{REZULTATŲ APTARIMAS}

Faktorinès analizès metu gauti duomenys patvirtino P. Tierney ir S. Farmer (2002), S. Farmer, P. Tierney ir K. Kung-McIntyre (2003) koncepcija, kad kūrybinis saviveiksmingumas ir subjektyvus kūrybiškumas nèra tapačios sąvokos. Abi sąvokos žymi asmens savivaizdžio aspektus, tačiau kūrybinis saviveiksmingumas rodo asmens pasitikejjimą savo kūrybiniais gebejjimais, o subjektyvus kūrybiškumas - asmens nuomonę, kiek kasdieniai jo rezultatai gali būti laikomi kūrybiškais. Abi šios sąvokos gali būti taikomos tik kūrybiškam specialistui apibūdinti. Sąlygiškai galima išskirti subjektyvų kūrybiškumą kaip svarbesnę kategoriją, kadangi kūrybinis saviveiksmingumas rodo potencialo issivertinimą, o subjektyvus kūrybiškumas - kaip šis potencialas buvo realizuotas veikloje. Pastebètas neatitikimas tarp kūrybinio saviveiksmingumo ir subjektyvaus kūrybiškumo. Kur kas daugiau mokytojų nurodo didesnį kūrybini saviveiksmingumą nei subjektyvuji kūrybiškumą. Verta tyrineti faktorius, kurie slopina motyvaciją mokytojo darbe panaudoti kūrybinius gebejjimus. Tyrimo duomenys leidžia ívardyti tik tuos veiksnius, kurie skatina kūrybiškumą profesinèje veikloje. Negatyvios emocijos neigiamai veikia subjektyvuji kūrybiškumą, tačiau šis poveikis nèra statistiškai reikšmingas. Tolesniais tyrimais būtų pravartu įvertinti, kaip socialinis kontekstas, asmens turima patirtis, jo kompetencija ir kiti faktoriai veikia subjektyvuji kūrybiškumą.

Faktorinès analizès duomenys atskleidè pozityviu, negatyvių ir neutralių emocijų skirtumus. Tyrimas patvirtino užsienio mokslininkų duomenis, teigiančius, kad pozityvios emocijos teigiamai veikia subjektyvuji kūrybiškumą. Kita vertus, negatyvių emocijų ir kūrybiškumo sąsajos iki galo nèra ištirtos - tarp jų nustatytas neigiamas ryšys, kuris nèra statistiškai reikšmingas.

Darbo motyvacijos šaltinių analizè leido išskirti tik tris faktorius vietoje penkių teoriškai numatytu. Šie rezultatai parode pedagoginès veiklos specifiškumą. Nepavyko išskirti instrumentinès motyvacijos ir vidinès savivaizdžio motyvacijos faktorių. Galima daryti prielaidą, kad du šie motyvu tipai mokytojams nèra svarbūs. Duomenys leido įvertinti, kad išorinè savivaizdžio ir vidinio tikslo motyvacija - labiausiai su subjektyviuoju kūrybiškumu susiję motyvų šaltiniai. Šie duomenys iš dalies patvirtina užsienio autorių išvadas: vidinè motyvacija glaudžiai susijusi su kūrybiškumu, tačiau išorinès motyvacijos poveikis kūrybiškumui dažniausiai vertinamas neigiamai.

Gauti duomenys papildo Vakarų mokslininkų pateikiamą darbuotojo kūrybiškumo sampratą. Patvirtinta, kad bendroji kūrybiškumą apibūdinanti 
teorija gali būti sèkmingai taikoma analizuojant mokytojo veiklą. Lietuvos mokslinès literatūros kontekste atkreipiamas demesys i mokytojų kūrybiškumo ugdymo poreiki, kadangi mokytojo kūrybiškumas tiesiogiai veikia mokinių kūrybiškumo ugdymą.

\section{IŠVADOS}

1. Naudojant faktorinès analizės procedūrą išgryninti aštuoni faktoriai, susiję su pedagogu kūrybiškumu profesinejje veikloje. Aukščiausias vidinio suderinamumo koeficientas nustatytas vidinio tikslo motyvacijos, kūrybinio saviveiksmingumo ir individualios paramos darbuotojui skalėmis. Vidini grupinių tyrimų suderinamumo kriterijų tenkina visos likusios skalès.

2. Nepatvirtinta teoriškai numatyta motyvacijos šaltinių struktūra, nes pedagoginèje veikloje išorinès savivaizdžio motyvacijos šaltinis kur kas dažniau stimuliuojamas nei vidinès, o materialaus skatinimo už profesinès veiklos rezultatus galimybės yra minimalios, pasiekiamos tik daliai mokytojų, atsižvelgiant ị mokyklos galimybes.

3. Nustatytos pedagogų suvokiamo kūrybiškumo profesinèje veikloje sąsajos su jų kūrybiniu saviveiksmingumu, darbe patiriamomis pozityviomis emocijomis ir darbo motyvacijos šaltiniais.

\section{LITERATŪRA}

Albert, R. S., Runco, M. A. (1999). A History of Research on Creativity. R. J. Sternberg (Ed.), Handbook of Creativity (pp. 16-31). Cambridge: Cambridge University Press.

Almonaitienè, J. (2000). Kūrybos ir inovaciju psichologija. Kaunas: KTU leidykla.

Amabile, T. M., Barsade, S. G., Mueller, J. S., Staw, B. M. (2005). Affect and Creativity at Work. Administrative Science Quarterly, 50, 367-403.

Amabile, T. M. (1996). Creativity in Context. Oxford: Westview Press.

Barbuto, J. E. (2005) Motivation and transactional, charismatic, and transformational leadership: A test of antecedents. Journal of Leadership and Organizational Studies, 11 (4), 26-40.

Cropley, A. (2006). Creativity: A social approach. Roeper Review, 28 (3), 20-27.

Domeikiené, K. (2005). I-II klasių mokinių, turinčių kalbos sutrikimu, verbalinio kūrybiškumo pokyčiai. $P e-$ dagogika, 80, 146-151.

Hennessey, B. A. (2003). The social psychology of creativity. Scandinavian Journal of Educational Research, 47 (3), 253-271.

Farmer, S., Tierney, P., Kung-McIntyre, K. (2003). Employee creativity in Taiwan: An application of role identity theory. Academy of Management Journal, 46 (5), $618-630$.

Ford, C. M., Gioia, D. A. (2000). Factors influencing creativity in the domain of managerial decision making. Journal of Management, 26 (4), 705-732.

Forshaw, M. (2007). Easy Statistics in Psychology. A BPS Guide. New York: Blackwell.

Hennessey, B. A. (2003). The social psychology of creativity. Scandinavian Journal of Research, 47 (3), 253271.

Grakauskaitè-Karkockiene, D. (2002). Kürybos psichologija. I leidimas. Vilnius: Logotipas.

Grakauskaitè-Karkockienè, D. (2006). Kūrybos psichologijos pagrindai. Vilnius: VPU leidykla.

James, K., Brodersen, M., Eisenberg, J. (2004). Workplace affect and workplace creativity: A review and preliminary model. Human Performance, 17 (2), 169-194.
Kačerauskas, T. (2005). Kultūros filosofija ir egzistencinè fenomenologija. Problemos, 68, 32-40.

Kačerauskas, T. (2007). Kultūra kaip egzistencinė kūryba. Problemos, 71, 49-58.

Karkockienè, D., Butkienė, G. (2005). Studentų kūrybiškumo ir intelekto gebejjimų sąsajos. Psichologija: mokslo darbai, 31, 60-74.

Kornacki, S. A., Caruso, D. R. (2007). A theory based, practical approach to emotional intelligence training: Ten ways to increase emotional skills. In J. Ciarrochi, J. D. Mayer (Eds.), Applying Emotional Intelligence (pp. 53-88). New York: Psychology Press.

Leonard, N. H., Beauvais, L. L., Scholl, R. W. (1999). Work motivation: The incorporation of self-concept based processes. Human Relations, 52, 969-998.

Lickert, R. (1932). A technique for the measurement of attitudes. Archives of Psychology, 140, 1-55.

Maceina, A. (1991). Raštai. T. I. Vilnius: Mintis.

Nam Choi, J. (2004). Individual and contextual predictors of creative performance: The mediating role of psychological processes. Creativity Research Journal, 16 (2), 187-199.

Petrulytè, A. (2008). Paaugliu kūrybiškumas ir sveikatos kontrolès lokusas kaip mokymosi sėkmès veiksniai. Pedagogika, 90, 115-120.

Ponelienè, R., Gumuliauskienė, A. (2008). Priešmokyklinio amžiaus vaikų kūrybiškumo apraiškos meninejje veikloje. Jaunuju mokslininku darbai, 1 (17), 98-105.

Pruskus, V. (2005). Kultūrinio kapitalo raiškos ypatumai. Problemos, 67, 48-62.

Sternberg, R. J., Lubart, T. I. (1999). The concept of creativity: Prospects and paradigms. In R. J. Sternberg (Ed.), Handbook of Creativity (pp. 16-31). Cambridge: Cambridge University Press.

Tierney, P., Farmer, S. (2002). Creative self-efficacy: It's potential antecedents and relationship to creative performance. Academy of Management Journal, 45 (6), $1137-1148$

Welle-Strand, A., Tjeldvoll, A. (2003). Creativity, curricula and paradigms. Scandinavian Journal of Educational Research, 47 (3), 359-372. 


\title{
ANALYSIS OF TEACHERS' CREATIVITY FACTORS IN THE DOMAIN OF PROFESSIONAL ACTIVITY
}

\author{
Dalia Lapėniené $\dot{\mathbf{e}}^{1}$, Skaistè Laskiene் $\dot{\mathbf{e}}^{2}$ \\ Kaunas Petras Vileišis Secondary School ${ }^{1}$, Lithuanian Academy of Physical Education ${ }^{2}$, \\ Kaunas, Lithuania
}

\begin{abstract}
During the last decade the scientists exploring organizational effectiveness have been interested in the social context of creativity and related personality factors. According to C. M. Ford and D. A. Gioia (2000) creativity should be defined as specific and subjective results which are novel and valuable. Creativity is analyzed as creative performance - individuals' expression of creative potential in their everyday behavior (Nam Choi, 2004). It is considered that everyday creativity is the key for success of every organization.

Teaching is a special domain where the social context is multidimensional and generating the resources for the development of individual creativity. Development of student's creativity is one of major goals of contemporary educational practice (Welle-Strand, Tjeldvoll, 2003). In this context creative teaching and teachers' professional creativity is of primary importance. It is important to find ways for enhancement teachers' professional creativity but for doing this we need to evaluate the actual level of teachers' professional creativity.

The aim of the study was to evaluate correlations between teachers' perceived creativity in the domain of professional activity and creative self-efficacy, work motivation and moods. The query was composed according to S. Farmer, P. Tierney, K. Kung-McIntyre (2003), P. Tierney ir S. Farmer (2002), S. A. Kornacki ir D. R. Caruso (2007), N. H. Leonard, L. L. Beauvais ir R. W. Scholl (1999). 190 teachers were asked to participate in the study. The data analysis was conducted using SPSS 16.0 for Windows.

The results disclosed the accordance between theoretical and empirical factors, which describe individual level of creativity analysis. Correlation analysis disclosed links between perceived creativity in the domain of teaching and creative self-efficacy, positive moods at work and work motivation sources.
\end{abstract}

Keywords: creativity, professional activity, perceived creativity.

Gauta 2008 m. lapkričio $27 \mathrm{~d}$.

Received on November 27, 2008

Priimta 2009 m. gegužès $6 \mathrm{~d}$.

Accepted on May 6, 2009

Dalia Lapènienè

Kauno Petro Vileišio vidurinè mokykla

(Kaunas Petras Vileišis Secondary School)

Demokratu g. 36, LT-48420 Kaunas

Lietuva (Lithuania)

Tel +370 67399455

E-mail dalia.1@mail.lt 